\title{
Characterization of Biochar Produced from Different Feed Stocks for Waste Management
}

\author{
Dereje Dejene $^{1 *}$ and Eyob Tilahun ${ }^{2}$ \\ ${ }^{1}$ Department of Natural Resource Management, Wolkite University, Ethiopia \\ ${ }^{2}$ Department of Natural Resource Management, Debre Tabor University, Ethiopia
}

Submission: July 21, 2019; Published: July 19, 2019

*Corresponding author: Dereje Dejene, Department of Natural Resource Management, Wolkite University, Ethiopia

\begin{abstract}
The objective of this study was to characterize the biochar produced from different agricultural wastes to explore its potential use as organic soil amendments. The feedstock of Eucalyptus globules (EG), Acacia decarance (AD), farmyard manure (FYM) and rice straw (RS) were collected and biochar was produced by slow pyrolysis at $300^{\circ} \mathrm{C}$ in the furnace. The biochar chemical composition was determined using standard laboratory procedure. Characterization of biochar mainly focused on chemical properties ( $\mathrm{pH}$, carbon, phosphorus, cation exchange capacity, electrical conductivity, exchangeable basic cations). Higher carbon content was observed in biochar produced from AD (65.00\%) compared with that of biochar produced from other feedstock type included in this study. $\mathrm{pH}$ value of Biochar produced from EG and RS showed moderately acidic ( $\mathrm{pH}$ 5.94) and neutral ( $\mathrm{pH}$ 6.6), respectively, whereas biochar produced from AD (pH 8.07 and FYM (pH 8.17) revealed moderately alkaline $\mathrm{pH}$ level. High and low EC values were recorded in biochar produced from FYM $\left(4.70 \mathrm{DS} \mathrm{m}{ }^{-1}\right)$ and EG $\left(0.68 \mathrm{DS} \mathrm{m}{ }^{-1)}\right.$, respectively. The maximum concentration of exchangeable magnesium (20.95\%), potassium $(16.40 \%)$ and sodium (1.77\%), EC and phosphorous (2288.75ppm) were testimony in biochar produced from FYM but calcium (39.50\%) was from biochar produced from AD. Higher CEC(129.75 cmolckg-1) was detected in biochar produced from EG followed by biochar produced from RS (127.5 $\left.\mathrm{cmolc} \mathrm{kg-}^{-1}\right)$, AD (117 $\left.\mathrm{cmolc} \mathrm{kg-1}\right)$, FYM $\left(87.25 \mathrm{cmolc} \mathrm{kg-}^{-1}\right)$. Generally, the current finding revealed that biochar from different feedstocks had different chemical properties, so this difference could contribute for soil fertility improvement as the result agricultural wastes is managed without pollution. But the current work was limited to the characterization of biochar. So, more detailed investigation on the rate and reclaiming the power of the biochar and other issues should be investigated.
\end{abstract}

Keywords: Biochar; Chemical characterization; Feedstock type; Agricultural waste management

\section{Introduction}

Conversion of agricultural wastes into Biochar is not only save natural resources, but also protects environmental pollution. Varies study of biochar effects in different soil substrates have been scientifically examined during the last decade and most of those findings proved positive effects on plant growth and soil properties [1]. Biochar has gotten high attention because of its potential use in many aspects like a soil amendment to improve soil quality [2], sequester carbon [36], inhibited loss of nitrogenous fertilizer, because biochar act as slow release fertilizer encapsulated [7] and filter potentially hazardous chemicals due to its strong sorption capacity to many contaminants [8].

Biochar from many sources of feedstock can be produced through the pyrolysis process in the absence of oxygen. Pyrolysis undergoes a variety of physical, chemical and molecular changes. volatilization during pyrolysis causes a significant loss in mass and therefore volume reduction and shrinking without causing much change in the original structure of the feedstock [9]. In addition, pyrolysis affects chemical properties of biochar like cation exchange capacity (CEC), $\mathrm{pH}$ and carbon content of biochar [10]. Biochar quality and quantity is mainly influenced by its feedstock type as well as pyrolysis condition [11]. Pyrolysis alters the nutrient content in the resulting biochar, which affects nutrient uptake by plants [12]

Several studies have been carried out to investigate the impacts of pyrolysis temperature on structural characteristics of biochar, sorption affinities to metals and physicochemical properties of different feedstocks [13]. However, the information concerning chemical properties of biochar produced from Eucalyptus globules, Acacia decarance, farmyard manure, and rice straw are limited. In other hand burning of crop residues in the field is a common practice during land preparation and disposal of waste like Eucalyptus globules and Acacia decrance trees have been used in the study area for charcoal production. During this production processes leaves, and branches of the 
trees were imprudently disposed and burned. These practices have been causing for environmental pollution and contribute to greenhouse gas emission to the atmosphere. Conversion of crop residue, eucalyptus and acacia tree byproduct biomass to biochar can be an alternative and sustainable way of waste management. However, information on the characteristics of biochar from this feedstock type was not studied. Therefore, the objective of this work was aimed to characterize biochar produced from different feedstocks based on chemical properties.

\section{Materials and Methods}

\section{Feedstock collection and biochar production}

The Eucalyptus and Acacia leave were collected from local charcoal production left over, farmyard manure from Debre Tabor University Tana-Guna Integrated Field Research Center and Rice straw from Fogera National rice research center. The feedstocks were kept in laboratory for air drying and the dried feedstocks were chopped with the help of clean knife. The prepared feedstock was placed in a ceramic crucible with a lid and then pyrolyzed in a furnace with the temperature rising to $300^{\circ} \mathrm{C}$ at a rate of $10^{\circ} \mathrm{C} / \mathrm{m}$ and maintained at the highest temperature for 2 hours and then followed by cooling to room temperature inside the furnace. Afterward, the Biochar sample was grounded and passes through a $2 \mathrm{~mm}$ mesh sieve and then transported to Bihar Dar Regional soil fertility improvement laboratory. Composite biochar samples from each biochar produced from different feedstock were prepared and analyzed for selected chemical properties.

\section{Analysis of chemical properties of biochar}

The $\mathrm{pH}$ of a biochar was determined in water at 1:2.5 biochar to water ratio [14]. Electrical conductivity was measured by a conductivity meter on standard biochar paste extracts obtained by Appling suction [15]. Organic carbon of the biochar was determined by following the wet digestion method as described by [16]. The available phosphorus was determined using the standard Olsen extraction method [17]. The exchangeable bases (Calcium, Magnesium, Potassium and Sodium) in the biochar were determined from the leachate of 1 molar ammonium acetate $\left(\mathrm{NH}_{4} \mathrm{OAc}\right)$ solution at $\mathrm{pH}$ 7. Exchangeable $\mathrm{Ca}$ and $\mathrm{Mg}$ were measured by atomic absorption spectrophotometer and, $\mathrm{K}$ and Na was read using flame photometer as outlined by [18]. Cation exchange capacity was determined at a soil $\mathrm{pH}$ level of 7 after displacement by using normal ammonium acetate with titrimetrically by distillation of ammonium that was displaced by sodium [19].

\section{Statistical analysis}

Statistical analyses were performed with the SAS statistical software version 9.2 software. The $\mathrm{pH}, \mathrm{EC}, \mathrm{CEC}, \mathrm{Ca}, \mathrm{Na}, \mathrm{Mg}, \mathrm{K}$ and $\mathrm{P}$ values were analyzed using one-way analysis of variance $(p<0.05)$ and non-significant $(p>0.05)$, were determined using the LSD test.

\section{Results and Discussion}

\section{Biochar conversion efficiency}

The current study showed that presence of significant difference in biochar yield production potential at $(\mathrm{p}<0.05)$. Those different feedstock types have different biochar yield production potential. The Higher biochar yield potential was recorded in $\mathrm{AD}$ (25.64\%) followed by FYM (21.55\%), EG (21.26\%) and RS (9.67) (Table 1). The possible reason for the difference in biochar yield production potential could be due to difference in lignin, cellulose and hemicelluloses content difference in feedstock. Similar finding is reported by [20]. In the other hand, lignocellulosic based biochar tends to have higher fixed carbon content than manure-based biochar [21].

Table 1: Biochar yield of biochar produced from different feedstock at $300^{\circ} \mathrm{C}$.

\begin{tabular}{|c|c|}
\hline Biochar Feedstock & Biochar Yield (\%) \\
\hline Eucalyptus & $21.26 \mathrm{~b}$ \\
\hline Acacia & $25.64 \mathrm{a}$ \\
\hline FYM & $21.55 \mathrm{~b}$ \\
\hline Rice Straw & $9.67 \mathrm{c}$ \\
\hline Means & 19.52 \\
\hline CV (\%) & 7.74 \\
\hline Standard Error & \pm 1.51 \\
\hline
\end{tabular}

Means with the same letter are not significantly different.

\section{Biochar reaction $(\mathrm{pH})$}

The highest $\mathrm{pH}$ was recorded in the biochar produced from FYM (8.17) followed by AD (8.07), rice straw (6.40) and EG (5.94). Biochar produced from FYM and Acacia decrance showed moderately alkaline $\mathrm{pH}$ level, but biochar produced from rice straw and Eucalyptus globules indicated moderately acidic $\mathrm{pH}$ level. Generally, $\mathrm{pH}$ value of Biochar produced from different feedstock has significant difference at $(p<0.05)$ (Table 2). Variability of $\mathrm{pH}$ value in between biochar produced from different feedstock type, but the pyrolysis temperature was same for all feedstock type, so that the biochar reaction difference is due to ash content difference in resulting biochar. This finding agrees with that of Ronsse et al. [22]. Higher pH values contain higher ash contents and their ash fraction contains more elements suitable for plant nutrients [23,24].

\section{Electrical conductivity (EC)}

Biochar produced from different feedstock have significantly influenced by different $(\mathrm{p}<0.05)$ in its electrical conductivity (Table 2). The highest electrical conductivity value was obtained from FYM biochar (4.70) and the lowest one was biochar produced from Eucalyptus globules (0.68). A possible reason for 
the highest EC value of biochar could be due to an increase of high soluble and exchangeable base cations as outlined by [25].

\section{Carbon (C)}

Maximum total carbon was produced from AD (65.50\%) followed by rice straw (40.90), EG (37.25) and FYM (23.25\%). Biochar produced from different feedstock have significant influence at $(\mathrm{p}<0.05)$ within its total carbon (Table 2). Biochar produced from manure feedstocks tend to have lower $\mathrm{C}$ content than lignocellulosic based feedstocks, because manure-based biochar's are related to the feedstock containing more volatile organic carbon compounds that are lost during the dry and carbonation processes [26].

Table 2: Biochar $(\mathrm{pH})$, electrical conductivity $(\mathrm{EC})$ and carbon content of biochar produced from different feedstock at $300^{\circ} \mathrm{C}$.

\begin{tabular}{|c|c|c|c|}
\hline \multirow{2}{*}{$\begin{array}{c}\text { Biochar } \\
\text { Feedstock Type }\end{array}$} & \multicolumn{3}{|c|}{ Chemical Properties } \\
\cline { 2 - 4 } & pH Water (1:2.5) & EC (ds/m) & Carbon (\%) \\
\hline Eucalyptus & $5.94 \mathrm{c}$ & $0.68 \mathrm{~d}$ & $37.25 \mathrm{c}$ \\
\hline Acacia & $8.07 \mathrm{a}$ & $3.79 \mathrm{c}$ & $65.50 \mathrm{a}$ \\
\hline FYM & $8.17 \mathrm{a}$ & $4.70 \mathrm{a}$ & $23.25 \mathrm{~d}$ \\
\hline Rice Straw & $6.40 \mathrm{~b}$ & $4.29 \mathrm{ab}$ & $40.90 \mathrm{~b}$ \\
\hline Means & 7.14 & 3.37 & 41.73 \\
\hline CV (\%) & 0.8 & 0.15 & 1.37 \\
\hline Standard Error & \pm 0.06 & \pm 0.26 & \pm 0.57 \\
\hline
\end{tabular}

Means with the same letter are not significantly different.

\section{Exchangeable basic cations ( $\mathrm{Ca}, \mathrm{K}, \mathrm{Mg}$ and $\mathrm{Na}$ )}

As presented in Table 3, there were significant difference at $(p<0.05)$ between feedstocks on exchangeable basic cations. FYM biochar contained the highest $\mathrm{Na}, \mathrm{K}$ and $\mathrm{Mg}$ content $(1.77,16.40$ and $20.95 \%$, respectively), while the highest Ca (39.50) was found in AD Biochar. Nevertheless, EG and RS biochar presented

the lowest contents of $\mathrm{Na}, \mathrm{K}, \mathrm{Ca}$ and $\mathrm{Mg}(1.10,4.38,15.05$ and $13.00 \%)$. The higher content of exchangeable basic cations in $\mathrm{AD}$ and farmyard manure biochar indicated that the relevant chemical components were concentrated in biochar during the pyrolysis of feedstock as explained by [27]. High calcium content is likely connected with the bioconversion of organic matter into Biochar causing an expected release of compounds as Ca that reacts with carbonate or phosphate and precipitates [28].

\section{Phosphorus (P)}

Maximum concentration of $\mathrm{P}$ was observed at biochar produced from farmyard manure $(2288.75 \mathrm{ppm})$ followed by rice straw (1761.50), Acacia decrance (381ppm) and Eucalyptus (339.9ppm) (Table 2). High content of P in the biochar could be due to the charring of organic materials that can highly enhance $P$ availability from plant tissue by disproportionately volatilizing $\mathrm{C}$ and by cleaving organic $P$ bonds, resulting in a residue with high soluble P salts associated with the charred material as outlined (Knoepp et al. 2005). The amount of phosphorus produced from different feedstock explained significant difference at $(\mathrm{p}<0.05)$ (Table 3).

\section{Cation Exchange Capacity (CEC)}

As presented in Table 3, the cation exchange capacity of a biochar produced from eucalyptus $\left(129.75 \mathrm{cmolc} \mathrm{kg-}^{-1}\right)$ and rice straw $\left(127.50 \mathrm{cmolc}_{\mathrm{kg}}{ }^{-1}\right)$ showed statistically non-significant difference. But lower value and statistically significance difference in biochar produced from FYM $\left(87.25 \mathrm{cmolc} \mathrm{kg}^{-1}\right)$ was observed. The analysis result of biochar revealed that biochar produced from eucalyptus had high nutrient retention and water adsorption capacity followed by rice straw, Acacia and FYM in addition to the direct supply of nutrients as CEC values indicated. Relatively high CEC value in biochar produced from eucalyptus and rice straw could be due to high oxygen-containing functional group [29].

Table 3: Inorganic element composition and cation exchange capacity of biochar produced from different feed stock sat $300^{\circ} \mathrm{C}$.

\begin{tabular}{|c|c|c|c|c|c|c|}
\hline \multirow{2}{*}{$\begin{array}{c}\text { Feedstock } \\
\text { Type }\end{array}$} & \multicolumn{6}{|c|}{ Biochar Chemical Properties } \\
\hline & Sodium (\%) & Potassium (\%) & Calcium (\%) & Magnesium (\%) & Phosphorus (ppm) & CECcmolc kg-1 \\
\hline Eucalyptus & $1.10 \mathrm{~d}$ & $4.83 \mathrm{~d}$ & $28.75 c$ & $19.50 \mathrm{~b}$ & $339.90 \mathrm{~d}$ & $129.75 a$ \\
\hline Acacia & $1.37 \mathrm{c}$ & $12.63 \mathrm{c}$ & $39.50 \mathrm{a}$ & $19.35 b$ & $381.00 \mathrm{c}$ & $117.00 \mathrm{~b}$ \\
\hline FYM & $1.77 \mathrm{a}$ & $16.40 \mathrm{a}$ & $35.30 \mathrm{~b}$ & $20.95 a$ & $2288.75 a$ & $87.25 c$ \\
\hline Rice Straw & $1.46 \mathrm{~b}$ & $13.12 b$ & $15.50 \mathrm{~d}$ & $13.00 \mathrm{c}$ & $1761.50 \mathrm{~b}$ & $127.50 \mathrm{a}$ \\
\hline Means & 1.42 & 11.74 & 29.76 & 18.2 & 1192.79 & 115.38 \\
\hline CV (\%) & 1.23 & 1.58 & 0.62 & 1.47 & 1.7 & 1.1 \\
\hline Standard Error & \pm 0.018 & \pm 0.19 & \pm 0.18 & \pm 0.27 & \pm 20.26 & \pm 1.27 \\
\hline
\end{tabular}

Means with the same letter are not significantly different.

\section{Conclusion}

The characterizations of biochar from different feedstock were explored by using the chemical properties of the biochar. Biochar produced from the pyrolysis of four feedstock sample at $300^{\circ} \mathrm{C}$ had a different biochar yield and chemical properties. The chemical variability of a biochar could have a positive contribution on soil conditioning, specifically biochar produced from farmyard manure and Acacia decrance may have potential to acid soil reclamation. However, the environmental pollution and ecological disturbance caused by residue disposal and burring cannot be ignored, because continuous disposable and burning agricultural wastes cause environmental pollution and contribute for greenhouse gas emission. The current study was limited to characterization. So, the rate determination 
and reclaiming powers of the biochar produced from different feedstock should be further studied.

\section{Acknowledgments}

The researchers would like to acknowledge Debre Tabor University for providing the financial support. The authors also would like to thank Mr. Antanh Abewa for the professional assistance during proposal development. Authors' deep gratitude and appreciation extends to the Bahar Dar soil fertility improvement, laboratory technicians for their tremendous help in laboratory analysis of the soil samples.

\section{References}

1. Glaser B, Lehmann J, Zech W (2002) Ameliorating physical and chemical properties of highly weathered soils in the tropics with charcoal. A review. Bio Fertil soil 35(4): 219-230.

2. Silber A, Levkovitch I, Graber E (2010) pH-Dependent Mineral Release and Surface Properties of Corn straw Biochar: Agronomic Implications. Environ Sci Technol 44(24): 9318-9323.

3. El-Naggar A, Awad YM, Tang XY, Liu C, Niazi NK, et al. (2018) Biochar Influences Soil Carbon Pools and Facilitates Interactions with Soil: A field investigation. Land Degrad Dev 29(7): 2162-2171.

4. Matovic D (2011) Biochar as a Viable Carbon Sequestration Option: Global and Canadian Perspective. Energy 36(4): 2011-2016.

5. Kuzyakov Y, Subbotina I, Chen H, Bogomolova I, Xu X, (2009) Black Carbon Decomposition and Incorporation into Soil Microbial Biomass Estimated by ${ }^{14} \mathrm{C}$ Labeling. Soil Biol Biochem 41(2): 210-219.

6. Spokas KA, Reicosky DC (2009) Impacts of Sixteen different biochar on soil greenhouse gas production. Ann Environ Sci 3: 179-193.

7. Songling C, Ming Y, Chuang B, Susu Y, Yifei J, et al. (2017) Preparation and Characterization of Slow-Release Fertilizer Encapsulated by BiocharBased waterborne Copolymers. Science of the total environment 615: 431-437.

8. Borchard N, Prost K, Kautz T, Moeller A, Siemens J (2012). Sorption of copper and sulphate to different biochar before and after composting with farmyard manure. Eur J Soil Sci 63(3): 399-409.

9. Laine J, Simoni S, Calles R (1991) Preparation of activated carbon from coconut shell in a small scale concurrent flow rotary kiln. Chem Eng Commun 99: 15-23.

10. Wu W, Yang M, Feng Q Mcgrouther K, Wang H, et al. (2012) Chemical characterization of rice straw-derived biochar for soil amendment Biomass Bioenergy 47: 268-276.

11. Haiqing Y, Kuichuan S (2012) Characterization of Biochar Properties Affected by Different Pyrolylsi Temperature Using Visible-NearInfrared Spectroscopy. ISRN Spectroscopy 2012(712837): 7.

12. Kuhlbusch T, Lobert J, CrutzenJ, Warneck P (1991) Molecular nitrogen emissions from denitrification during burning. Nature 351:135-137.

13. Uchimiya M, Wartelle L, Klasson K, Fortier C, Lima I (2011) Influence of pyrolysis temperature on biochar property and function as a heavy metal sorbent in soil. J Agri Food Chem 59(6): 2501-2510.
14. Van Reeuwiik L (1993) Procedures for soil analysis. ( $4^{\text {th }}$ edn), Technical paper 9 ISRIC, Wagningen, the Netherlands.

15. OkaleboJ, Gathua K, Womer P (2002) Laboratory methods of soil and plant analysis: a working manual. $\left(2^{\text {nd }} \mathrm{edn}\right)$, TSBF-CIAT and SACRED Africa, Nairobi, Kenya.

16. Walkley A, Black C (1934) An examination of different methods for determining soil organic matter and the proposed modifications by the chronic acid titration method. Soil Sci 37(1): 29-38.

17. Olsen S, Cole C, Wanatabe F, Dean L (1954) Estimation of available phosphorus in soil by extraction with sodium bicarbonate. USDA circular 939: 1-19.

18. Rowell D (1994) Soil science: method and applications. Addison Wesley longman limited, England.

19. Chapman H (1965) Cation exchange capacity. In: Black CA (Ed.), methods of soil analysis. American society of Agronomy, Wisconsin, USA, pp. 891-901.

20. Yongwoon L, Jinje P, Ki Seop G, Changkook R, Won Y, et al. (2014) Production and Characterization of Biochar from Various Biomass Materials by slow Pyrolysis. School of mechanical engineering, South Korea, pp. 1-11.

21. Domingues RR, Trugilho PF, Silva CA, De Melo IC, Melo LCA, et al. (2017) Properties of Biochar Driven from Wood and High Nutrient Biomass with the aim of agronomic and environmental benegits. PLos One 12(5): e0176884.

22. Ronsse F, Sven Van H, Dane D, Wolter P (2013) Production and Characterization of Slow Pyrolysis Biochar: Influence of Feedstock Type and Pyrolysis Conditions. Biosystems Engineering, Ghent Nniversity, Belgium.

23. Cantrell KB, Hunt PG, Uchimiya M, Novak JM, Ro KS (2012) Impact of Pyrolysis Tempertature and Manure Source on Physicochemical Characteristics of Biochar. Biores Technol 107: 419-428.

24. Ippolito JA, Spokas KA, Novak JM, Lentz RD, Cantrell KB (2015) Biochar Elemental composition and Factors Influencing nutrient Retention In: Lehmann J, Joseph S (Eds.), Biochar for environmental management science, technology and implementation. ( $2^{\text {nd }}$ edn), earthscan, Routledge Pupl., London, UK, pp. 139-164.

25. Demirbas A (2007) The Influence of Temperature on the Yields of Compounds Existing in Bio-oils Obtained from biomass samples via pyrolysis. Fuel Process Technol 88(6): 591-597.

26. Novak JM, Johnson MJ (2019) Elemental and Spectroscopic Characterization of Low Temperature $\left(350^{\circ}\right)$ Lignocellulosic and Manure Based Designer Biohars and Their Use as Soil Amendments.

27. Yuan J, Xu R, Zhang H (2011) The forms of alkalis in the biochar produced from crop residues at different temperatures. Bio Resource Technol 102(3): 3488-3497.

28. Carchesio M, Tatano F, Lancellotti I, Taurino R, Colombo E, et al. (2014) Comparison of Biomethane Production and Digestate Characterization for Selected Agricultural Substrates in Italy. Environ Technol 35(1720): 2212-2226.

29. Chan K, Xu Z (2009) Biochar nutrient properties and their enhancement. In: Lehmann J, Joseph S (Eds.), Biochar for environmental management: Science and technology. Earthscan, London, pp. 53-66. 
(C) This work is licensed under Creative
Your next submission with Juniper Publishers will reach you the below assets

- Quality Editorial service

- Swift Peer Review

- Reprints availability

- E-prints Service

- Manuscript Podcast for convenient understanding

- Global attainment for your research

- Manuscript accessibility in different formats ( Pdf, E-pub, Full Text, Audio)

- Unceasing customer service

Track the below URL for one-step submission https://juniperpublishers.com/online-submission.php 